\title{
7 才児でもブジ一療法が有効であった遷延性の 新生児涙囊炎の一例
}

大塚 正博 ·大久保 享一・坂本 博士・魚住 博彦・栗本 晋二 産業医科大学眼科学教室

要旨：先天性鼻滬管閉塞が原因と考えられる慢性涙慗炎に対してブジ一療法を行い，良好な結果 をうることができた一例をここに報告した。症例は7才男子で，年長児における慢性涙霊 炎は，一般的にブジ一療法の適応外といわれているが，本症例のように現病歴なよ゙により

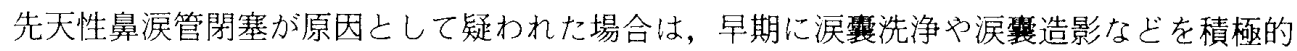
に行い，涙囊鼻腔吻合術の適応と考えられる症例に対しても術前に閉塞部位の確認のため にも慎重にブジーを行うべきである。

(1984 年5月 15 日 受付)

緒

\section{言}

先天性鼻涙管閉塞は乳児涙囊炎を惹起し，稀な疾患 ではないが日常の診療において難治性結膜炎や眼瞼内 反症などの疾患との鑑別も容易ではない場合も多く， 発病初期に適切な治療，すなわちブジー療法，が行わ れず遷延化することによりブジ一療法の適志外となる 症例も少なくない，先天性鼻涙管閉塞の涙道ブジ一は 生後 $3-5$ か月以後に遅らすべきではないとされてい る. 早期に行うほ上゙治愈率は高く, 時期を冕すると, 涙囊鼻腔吻合術のような大きな手術を要することにな るからである。しかし我々は7才児にみられた遷延性 の先天性鼻涙管閉塞症に起因すると考えられた慢性涙 襄炎症例に対して，ブジー療法を行い良好な結果を得 ることができたのでここに報告する。

症例

症例：H.M. 7 才 7 月 男子

初診：昭和 58 年 8 月 18 日

主訴：右眼流涙，右眼眼瞼皮膚の発赤びらん

現症歴：1才頃より右眼の流涙と眼脂の増量に母親 が気づき近医を受診するも，症状は持続したがその後 放置していた。，小学校入学頃より右眼眼瞼皮膚の発赤
びらんが加わり，再び近医を受診し，当科に紹介され， 手術目的のために入院となった。

家族歴：特記すべき事項なし。

既往歴：昭和 52 年, 昭和 53 年の 2 回にわたり斜頸 の手術, 昭和 55 年狭頭症の手術を受けた。

初診時所見: 視力: 右, $0.6(0.8 \times \mathrm{S} .-0.5 \mathrm{D}$ cyl. $+0.75 \mathrm{D}$ Axis $\left.90^{\circ}\right)$, 左, $0.9(1.2 \times \mathrm{S} .-0.5 \mathrm{D})$, 眼圧：右, $14.6 \mathrm{mmHg}$, 左, $17.3 \mathrm{mmHg}$ (Schiötz); 外眼部: 右, 流滬 $(+)$, 眼瞼皮膚の発赤びらん $(+)$, 内眼角部に眼脂の付着 $(+)$, 睫毛内反 $(-)$, 眼瞼結 膜充血軽度 $(+)$, 眼球結膜充血 $(-)$, 左, 異常なし; 眼位：正位; 眼球運動：正常. 前眼部 - 中間透光体 眼底：両眼之も異常なし，右眼に流涙を認めたため， 右涙整部を王迫したところ，黄色の粘調な膿が下涙点 より流出した。次に下涙点より涙囊洗浄を行ない, 上 淭点よりの洗浄液の流出と膿の排出を確認し, 右眼慢 性涙震炎と診断し，閉塞部位確認のために涙囊造影を 行った。造影所見はFig. 1A,Bのごとく右椖襄は㹡 大し，涙整鼻涙管移行部での閉塞所見が得られた。そ のため沪整鼻腔吻術の適応と考え, 手術目的で入院と なった。

経過：入院時より右眼に対し抗生剂コリマイC ${ }^{\circledR} の$ 点眼と济囊洗浄を朝夕 2 回行い, 洗浄時に流出した洗 浄液抢よび膿を採取し，細菌培養を行った。培養の結 

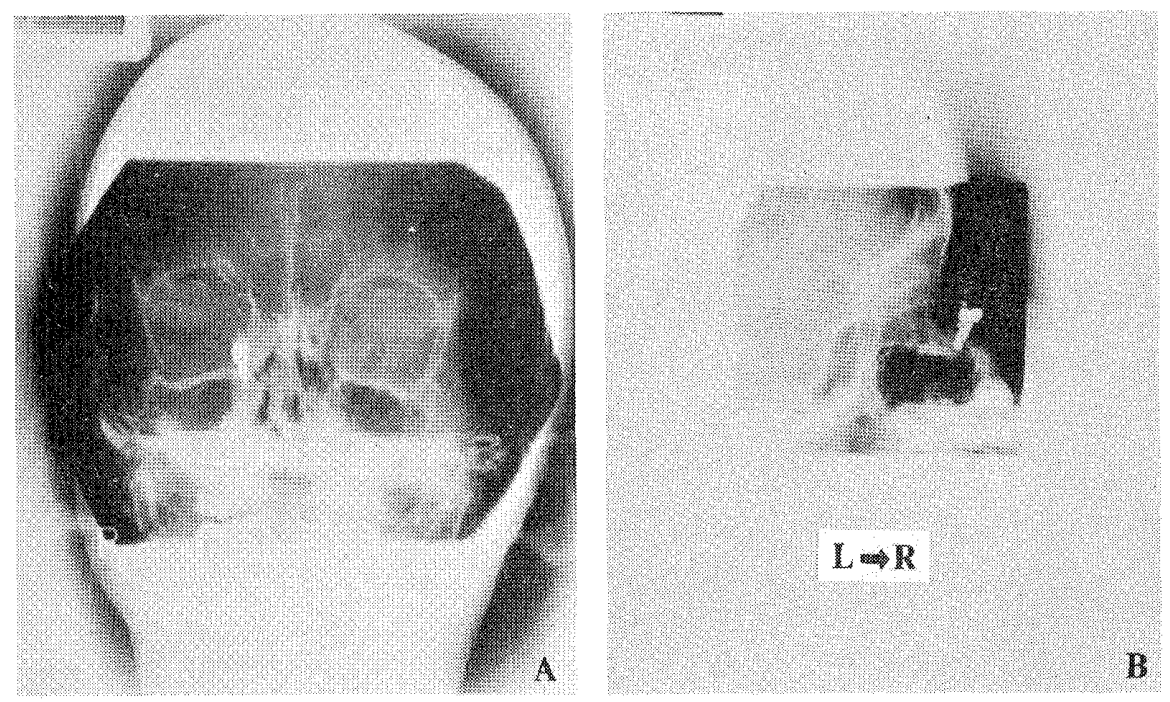

Fig. 1. Dacryocystograms of a seven-year-old male with dacryocystitis, contrasting complete obstruction of right nasolacrimal duct with extension of lacrimal sac.

A: A-P view, B: Lateral view

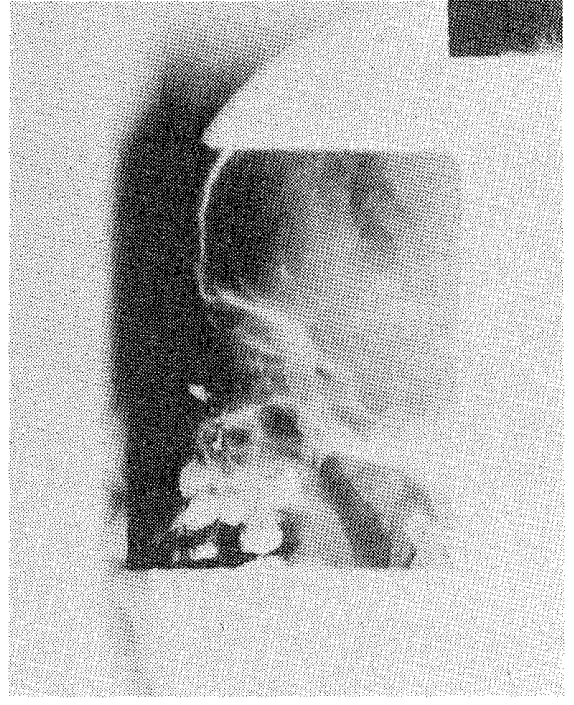

Fig. 2. A dacryocystogram on four days after probing of the duct. The obstruction is removed.

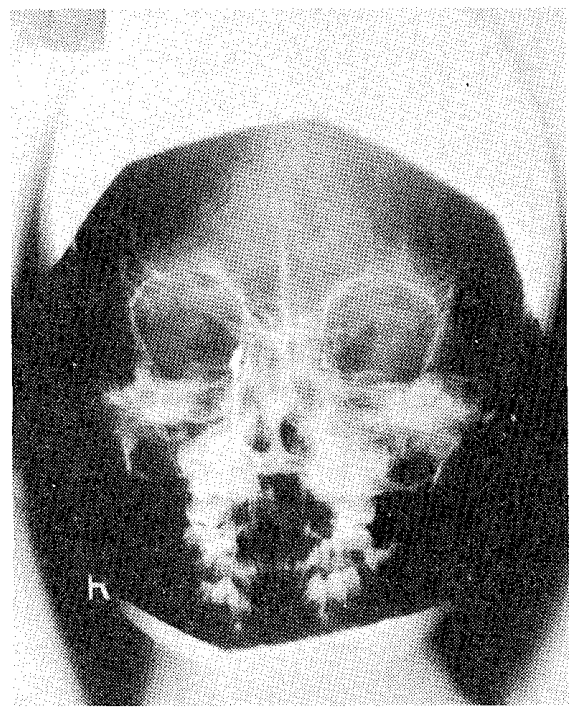

Fig. 3. A dacryocystogram showing the enlarged right lacrimal sac compared with the left sac.

コリマイ $\mathrm{C}^{\mathrm{R}}$ の点眼疼4日間行い，全身的にはケフ ラールドライシロップ® $30 \mathrm{mg} / \mathrm{kg}$ を 4 日間経口投与 した.Fig. 2 はブジー療法後 4 日目に行った在涙囊 造影の側面像である。造影剂の下鼻道への流出が確認 できた。左在涙囊を比較すると明らかに右涙囊の拡大 が確認できた（Fig. 3).

臨床症状としては，ブジ一療法後，翌日より流浣， 眼脂ともほとんど消失し涙霊洗浄の膿の逆流は翌朝の みわずかに認められたが，鼻腔内への洗浄液の流出は 良好であった。術後 2 日目より膿の逆流もなく鼻腔内 
への流出も良好なためブジ一蟟法後 7 日目に退院し, 外来にて週 1 回の割合で涙囊洗浄を行った。退院後 2 か月経過した時点で流滬・眼脂は全く消失し眼瞼皮膚 の発赤びらんもなく良好な結果を得ている。

\section{考按}

新生児において流涙および眼脂の増量を主訴とする 症例は少なくなく，これらの症例に涙翼洗浄を行うと 約 $50 \%$ は先天性鼻涙管閉塞症であったと報告されて いる（黒住・二宮，1972）。乙かし，先天性鼻涙管閉 塞の症例が新生児期に正しく先天性鼻涙管閉塞症と診 断され適切な治療を受けるとは限らず，丸尾・他 （1969）によると，結膜炎や内反症の診断のもとに治 療をうける症例も少なくないと報告されている。本症 は早期発見が重要で，発見できれば一度のブジー療法 にて大部分完治するといわれている，一方，前述のご とく，他疾患との鑑別が不十分なため適切な時期に適 切な治療を受けずに，本症例のように7才になるまで 放置される症例も稀に経験する。そのため，本症の適 切な治療を行うにあたっては早期発見が重要であり，
早期発見のポイントとして次の 4 項目があげられてい る.1) 流涙と眼脂が持続する。2) 眼脂が多い割に 結膜がきれいである。3）涙霬部を指圧すると滬点よ り膿が流出する。4) 洪囊洗浄液の逆流. (井上, 1969) 以上の所見より本症が疑われた場合は，必ず涙露洗浄 を行い，診断を確定し早期ブジ一療法を行うことが重 要である。

一般に本疾患が年長児に至るまで遷延化した場合は ブジー療法が奏功しないことが多いといわれている (井上，1976）。その理由として，鼻涙管上皮の発育 は生下時に最も活発で，成長に伴い徐々に減少するこ と，長期間の閉塞のために線維化・感染に上る狭窄・ 痽痕性変化が起こることがあげられている。しかし，

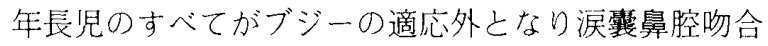
術の適応よるわけではない，年長児においても本症 例のように，現病歴などより先天性鼻涙管閉塞が涙囊 炎の原因として考えられる場合は，涙㹕鼻腔吻合術な ビの手術を施行する前に閉塞部位の確認の目的も兼ね て，ブジ一療法を一度は試みるべきであることを強調 したい.

文献

井上浩彦 (1969): 先天性鼻涙管通過障害．眼科, 11: 350-357.

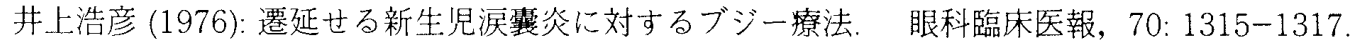

黒住 格・二宮俶子 (1972): 小児涙道疾患の統計および考察。臨床眼科，26: 121-125.

丸尾敏夫・久保田伸枝・谷合方子・他 (1969): 小児涙道疾患の治療。日本眼科紀要，20: 792-796 
Chronic Dacryocystitis Cured by Probing of the Duct

Masahiro Ohtsuka, Kyoichi Ohкubo, Hiroshi Sakamoto, Hirohiko Uozumi and Shinji KURIMOTO

Department of Ophthalmology, School of Medicine, University of Occupational and Environmental Health, Japan. Kitakyushu 807, Japan

Abstract: A seven-year-old case with chronic dacryocystitis resulting from congenital obstruction of the nasolacrimal duct was cured not by a dacryocystorhinostomy but by probing of the duct. Our results show that even in case of planned dacryocystorhinostomy, probing of the duct should be performed at least once.

Key words: dacryocystitis, probing, lacrimal obstruction.

J. UOEH, 6 ( 3 ): 303-306 (1984) 